\title{
Laser Induced Damage in Optical Glasses
}

\author{
By

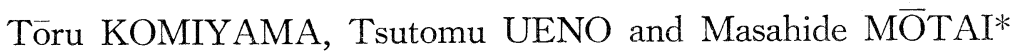 \\ (Government Industrial Research Institute, Osaka) \\ * Ohara Optical Glass Mfg. Co., Ltd.
}

\section{Introduction}

It is very important to construct a high power glass laser from the view point of its significant application to the research of plasma production, nonlinear optics, laser rader and so on. For this purpose, the glasses as the laser element with high durability against laser light have to be developed. Although many workers ${ }^{1) \sim 6}$ ) have investigated up to this time the damage resistance to laser light for glasses of different compositions, it appears that the fundamental and important problem, such as relation between the glass composition and the durability, on the development of the glasses for high power laser is still not sufficiently clear.

As a part of the subject to develop the most suitable glass for high power laser ${ }^{7)}$, the present work has been undertaken with the purpose of obtaining the information about the durability of glass, particularly its compositional dependency, against laser light. In this paper, the damage thresholds of different types of optical glasses by $\mathrm{Q}$-switched laser beam were determined, and further correlation of the durability with the glass composition and dominant factor regulating this were discussed.

Damage in glass and other transparent dielectrics could be divided into two types; internal and surface damage. The emphasis in this work was on internal damage, since the variations in the damage thresholds with the glass composition were more noticeable for internal damage.

\section{Experimental}

Optical glasses were selected as sample because of their high optical homogeneity. Inhomogeneity in sample makes it more difficult to determine the accurate damage threshold. About eighty glasses were randomly chosen. Experiments were carried out using fine-annealed block specimens of $15 \times$ $30 \times 50 \mathrm{~mm}$ in size. Laser beam passed through the sample across the optically polished parallel $15 \times 30 \mathrm{~mm}$ surfaces.

Glass laser beam was focused in the sample, and the damage thresholds were determined by increasing laser powere gradually.until the damage

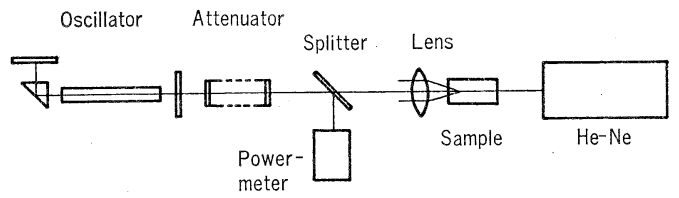

Fig. 1. Arrangement to measure the damage threshold for glass.

was observed. A block diagram of the experimental setup is shown in Fig. 1. The oscillator glass rod was $100 \times 10 \mathrm{~mm}$ in diameter. A part of the laser beam was diverted to a calibrated photodiodesynchroscope combination to measure the power and the pulse duration. The average output power was about $30 \mathrm{MW}$ in peak power and 20 nsec in half width. Through the measurement, a constant pumping power was applied so as to regulate as much as possible these values. Power density was controlled over wide range by varying both the focal length of the focusing lenses and the transmittance of the attenuator. To avoid the effect of self-trapping on the threshold, the lenses having a relatively short focal length were used and the laser beam was focused at $10 \mathrm{~mm}$ inside from the entrance surface of sample. A size of focal spot was determined by measuring the diameter of the damage spots on cupper target with microscope.

\section{Results}

In general, values of the damage threshold agreed within $\pm 10 \%$ for each samples (Table 1 ). For some samples, however, a great spread for the power density causing the damage was recognized. This seems to be due to optical inhomogeneity in the samples such as strain, striae, inclusion and so on. For example, it was impossible to determine the thresholds of samples

Table 1. Reproducibility of the damage threshold.

\begin{tabular}{lcc}
\hline Glass designation & \multicolumn{2}{c}{ Damage threshold $\left(10^{9} \mathrm{~W} / \mathrm{cm}^{2}\right)$} \\
\hline KF 1 & $5.50 \pm 0.08$ & $(2)$ \\
BaSF 1 & $3.00 \pm 0.12$ & $5.81 \pm 0.18$ \\
F 2 & $3.07 \pm 0.01$ & $3.10 \pm 0.05$ \\
SF 5 & $2.74 \pm 0.05$ & $3.09 \pm 0.10$ \\
LaSK 01 & $6.07 \pm 0.27$ & $2.68 \pm 0.08$ \\
\hline
\end{tabular}


purposely strained to the extent of 100 to 300 $\mathrm{m} \mu / \mathrm{cm}$ because, compared with the samples finely annealed, the damage sometimes occurred at lower power density, and sometimes the damage was not observed even at extremely high power. Since all the samples used in this work were finely annealed, influence of strain, as well as striae, need not be taken into the consideration. Therefore, the spread of the power density causing the damage may be principally attributed to the existence of inclusions such as microparticles of platinum. In fact, it was observed in the case of samples made in platinum crusible that the damage occurred not only at the power density below the thresholds but also even in the path of the laser beams in the vicinity of the focal spot. This is because the platium particles serve as the damage site to the passage of the laser beam $^{23,4)}$. The subject of this work is the intrinsic damage thresholds of glasses without inclusions. Consequently, we have to distinguish between the damage due to glass itself and due to inclusions, and it was possible by the observation of profile of the damage and the evaluation of the power density. Under the microscope, the damage caused by platinum particles appeared as a disk and the thresholds were estimated to be less than about one tenth of the intrinsic values.

The results of the measurement are summarized in Table 2. It is found that the damage thresholds, namely the durability of glass against laser light, considerably vary with the types of the glasses.

In order to obtain the information about relation between the glass composition and the damage threshold, we classified the glasses by compositions in six groups. The grouped glasses

Table 2. The damage thresholds for optical glasses.

\begin{tabular}{|c|c|c|}
\hline $\begin{array}{l}\text { Damage threshold } \\
\left(10^{9} \mathrm{~W} / \mathrm{cm}^{2}\right)\end{array}$ & Glass designation & $\begin{array}{l}\text { Ratio } \\
(\%)\end{array}$ \\
\hline$\sim 3.00$ & $\begin{array}{l}\mathrm{BaF} 12, \mathrm{BaSF} 1, \mathrm{BaSF} 3, \mathrm{BaSF} 8, \\
\mathrm{SF} 5, \mathrm{SF} 13, \mathrm{SF} 14\end{array}$ & 9.2 \\
\hline $3.01 \sim 4.00$ & $\begin{array}{l}\text { BaLF 6, BaF 2, BaF 3, BaF 6, } \\
\text { BaSF 4, LLF 1, LLF 2, LLF 3, } \\
\text { LF 2, LF 6, LF 7, F 1, F 2, F 4, } \\
\text { F 5, F 8, LaSF } 010\end{array}$ & 22.4 \\
\hline $4.01 \sim 5.00$ & $\begin{array}{l}\text { K } 3 \text {, SK } 3 \text {, SSK } 1, \text { SSK } 2, \text { ZK } 5 \text {, } \\
\text { BaLF } 3, \text { BaLF } 5, \quad \text { BaF } 4, \quad \text { F } 3 \text {, } \\
\text { LaF } 2, \text { LaSF } 5, \operatorname{LaSF} 08, \operatorname{LaSF} \\
015\end{array}$ & 17.1 \\
\hline $5.01 \sim 6.00$ & $\begin{array}{l}\text { BK } 3, \operatorname{BK} 6, \text { BK } 7, \text { SK } 2, \text { SK } 4, \\
\text { SK } 7, \quad \text { SK } 16, \quad \text { FK } 5, \quad \text { BaLF } 4, \\
\text { KF 1, LLF } 8, \operatorname{KzF} 4, \quad \operatorname{LaSK} 02, \\
\operatorname{LaF} 05\end{array}$ & 18.4 \\
\hline $6.01 \sim 7.00$ & 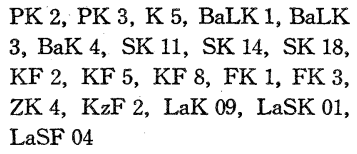 & 25.0 \\
\hline $7.01 \sim$ & $\begin{array}{l}\text { BK 10, PSK } 1, \quad \text { PSK } 2, \quad \text { ZK } 7, \\
\operatorname{BaK} 1, \operatorname{BaK} 2\end{array}$ & 7.9 \\
\hline
\end{tabular}

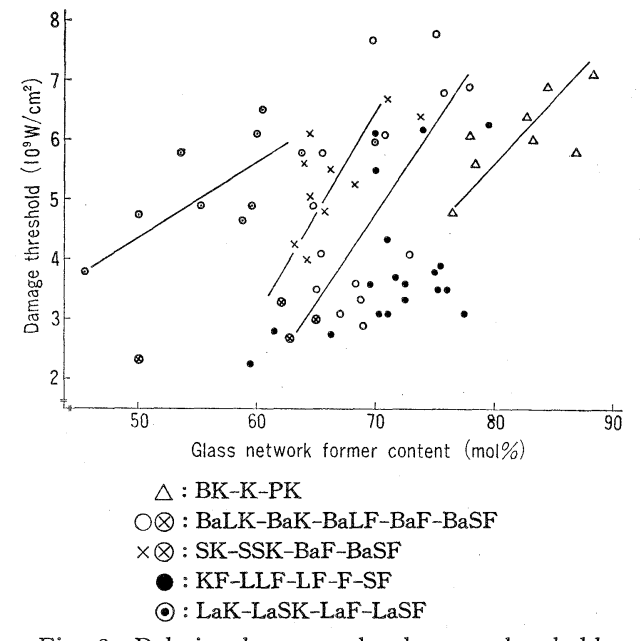

Fig. 2. Relation between the damage thresholds and content of the network former.

have almost similar components ${ }^{8), 9)}$. A plot of thresholds against content of the network former, $\mathrm{SiO}_{2}$ and $\mathrm{B}_{2} \mathrm{O}_{3}$, are given in Fig. 2. We note the following features of the results.

1) The thresholds increase with the increase of content of the network former.

2) The thresholds are high in glasses containing $\mathrm{BaO}$ and $\mathrm{La}_{2} \mathrm{O}_{3}$ as network modifier, while markedly low in glasses containing $\mathrm{PbO}$.

3) In a series of the glasses containing $\mathrm{La}_{2} \mathrm{O}_{3}$, the dependence of the thresholds upon the content of the network former is relatively weak. This seems to be related to packing effect of $\mathrm{La}^{3+}$ on glass structure ${ }^{10)}$.

We have tried to find out correlation of the damage thresholds with various physical properties of the glasses to clarify the dominant factor regulating the durability of glass against laser light. As the result, we have found that the thresholds are closely related with some optical and thermal properties.

A plot of the thresholds against Abbe's number is shown in Fig. 3. It is obviously recognized

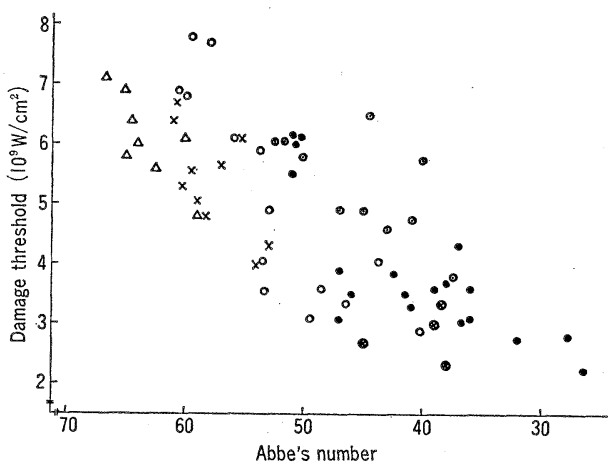

Fig. 3. Relation between the damage thresholds and Abbe's number. 
that the thresholds are higher in the glasses with the low dispersion than those with the high dispersion. In other words, the thresholds increase as the dispersion decreases. Since Abbe's number could be regarded as the function of the inherent frequency of absorption ${ }^{10)}$, this result shows that the thresholds increase with the increase of the frequency.

Fig. 4 shows a plot of the thresholds against average dispersion defined as $n_{\mathrm{F}}-n_{\mathrm{C}}$, where $n_{\mathrm{F}}$ and $n_{\mathrm{C}}$ are the refractive indices measured with $\mathrm{F}$ and $\mathrm{C}$ line respectively. The thresholds of the glasses containing $\mathrm{La}_{2} \mathrm{O}_{3}$ are found to be high in comparision with the other glasses having about the same average dispersion. Since it is known that the average dispersion approximately depends on the compactness of glass structure as well as the inherent frequency ${ }^{10)}$, this result may be attributed to the increase of the compactness characteristic of the glasses containing $\mathrm{La}_{2} \mathrm{O}_{3}$; it is considered that the increase of the average dispersion is chiefly due to the increase of the compactness rather than due to the decrease of the inherent frequency, and the thresholds in the glasses with the dispersion thus given are relatively high.

After all, we may conclude that the durability of glass against laser light largely depends on the

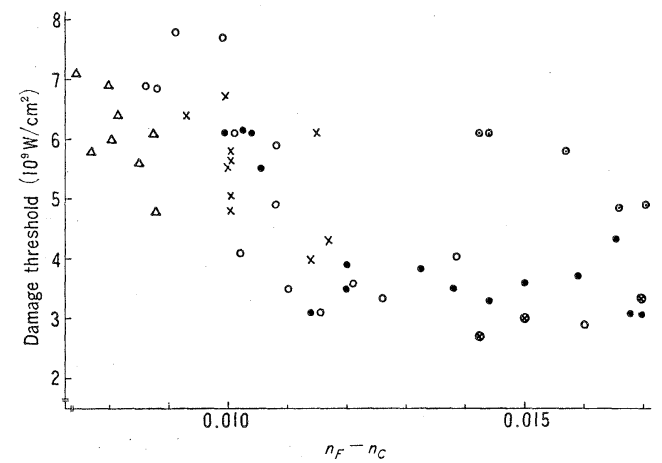

Fig. 4. Relation between the damage thresholds and the average dispersion, $n_{\mathrm{F}}-n_{\mathrm{C}}$.

Table 3. Relation between the damage thresholds and some physical properties.

\begin{tabular}{lccccc}
\hline $\begin{array}{c}\text { Glass } \\
\text { designation }\end{array}$ & $\left.\begin{array}{c}\text { Damage } \\
\text { threshold } \\
\left(10^{9} \text { W/cm }\right.\end{array}\right)$ & $\begin{array}{c}\text { Thermal } \\
\text { diffusivity } \\
\left(\mathrm{cm}^{2} / \mathrm{sec}\right)\end{array}$ & $\begin{array}{c}\text { Softening } \\
\text { point } \\
\left({ }^{\circ} \mathrm{C}\right)\end{array}$ & $\begin{array}{c}\text { Expansion } \\
\text { coefficient } \\
\left(\times 10^{7}\right)\end{array}$ & $\begin{array}{c}\text { Young's } \\
\text { modulus } \\
\left(\mathrm{kgW} / \mathrm{mm}^{2}\right)\end{array}$ \\
\hline BaK 1 & 7.70 & 4.33 & 749 & 88 & 7270 \\
BaLF 5 & 4.07 & 4.00 & 636 & 106 & 7310 \\
BaF 6 & 3.48 & 3.48 & 750 & 83 & 6760 \\
BaSF 4 & 3.36 & 3.20 & 657 & 97 & 8730 \\
SK 7 & 5.53 & 3.61 & 764 & 76 & 8190 \\
SSK 2 & 4.28 & 3.25 & 767 & 76 & 7780 \\
KF 8 & 6.16 & 4.13 & 613 & 100 & 5680 \\
LLF 1 & 3.50 & 4.18 & 592 & 97 & 6190 \\
LF 2 & 3.33 & 3.52 & 594 & 100 & 6080 \\
F 8 & 3.59 & 3.76 & 590 & 96 & 5900 \\
\hline
\end{tabular}

inherent frequency of absorption, but, on the other hand, the increase of compactness of oxygen ion in glass structure is also effective to increase the durability.

Furthermore, it was also found that the thresholds correlated with refractive indices. Namely the thresholds tend to increase as refractive indices become lower. However, the correlation is not so clear as with the dispersion.

Representative results about relation between the thresholds and other physical properties are given in Table 3 . Obvious correlation with the thermal diffusivity, which was determined with laser flash method, is recognized; in the glasses with the high thresholds, the thermal diffusivity is also high.

\section{Discussion}

\subsection{Dominant factor regulating the dura-} bility of glass against laser light

About the damage of transparent dielectrics such as glass by laser light, various possible mechanisms have been proposed up to dat $\mathrm{e}^{6), 11) \sim 14)}$, but the process leading to the damage is not yet fully understood. For instance, the multiphoton process alone can not explain the existence of microplasma produced prior to the damage and order of the damage thresholds is not necessarily related to the number of free electrons liberated by the multiphoton ionization ${ }^{13}$.

In all the theories of the damage, the liberation of free electrons and the electron-lattice interaction play important role ${ }^{6), 12) \sim 16)}$. Recently, Sharma and Rieckhoff considered that through the process in which free electrons liberated in the early part of a laser pulse by the multiphoton ionization absorb energy from the remainder of the pulse by inverse bremesstrahlung mechanism and multiply, the generation of the plasma which has essentially a role of the damage is caused, and evaluated the damage threshold from the point of view of the laser flux required for causing such multiplication ${ }^{16)}$. Namely, the photon flux, $S$, at which as to electrons the average rate of gain of energy is balanced by the average rate of loss is given by

$$
S=v m \bar{W} \delta^{-3 / 2} / h \omega M
$$

where $v$ is the velocity of electrons, $m$ the mass of electrons, $M$ the mass of atoms or ions in lattice, $h \omega$ the photon energy of laser light and $\bar{W}$ the average electron energy which is equal to half the ionization energy, respectively. If the photon flux of incident laser light is larger than the value given by (1), the rate of gain of energy exceeds the rate of loss due to elastic collisions with the 
lattice, and accordingly the multiplication of electrons takes place at a very rapid rate and the damage will be induced.

It follows from (1) that the damage threshold predominantly depends on $\delta$, electron-lattice collision cross section. As the large $\delta$ means the small mobility of electrons, this is thought to correspond to the low frequency of lattice ${ }^{12)}$; though the thresholds decrease with the increase of $\delta$, this may be attributed to the decrease of the frequency of network structure of glass. Then also $\bar{W}$ and $M$ are quantities varying with the types of glasses. Based upon Sharma's consideration by which multiphoton ionization of glass takes place at the bridging as well as the nonbridging oxygens ${ }^{13}$, we assume that these quantities are of oxygen ions. Thus $\bar{W}$ becomes another important parameter. As $\bar{W}$ may be approximately substituted by ionization potential of glass ${ }^{16)}$, the threshold is thought to depend on the magnitude of transition energy of electron or forbidden-band width in oxygen ion. After all, it may be qualitatively considered following Sharma and Rieckhoff that the durability of glass against laser light chiefly depends on both the frequency of network and energy gap in oxygen ion.

Now the result that the variations in the damage thresholds are largely due to the variations in the inherent frequency of absorption, as mentioned in previous section, may be interpreted in connection with these two factors. When some inherent absorption bands exist over the range of ultra-violet to infra-red region, the dispersion of light is given $b^{17}{ }^{17}$

$$
n^{2}-1=\sum_{u} \frac{N e^{2} f_{u}}{m\left(\nu_{u}^{2}-\nu^{2}\right)}+\sum_{r} \frac{N e^{2} f_{r}}{M\left(\nu_{r}^{2}-\nu^{2}\right)} \cdots
$$

where $n$ is the refractive index, $N$ the number of atoms or ions in unit volume, $e$ the charge of electron, $\nu$ the frequency of light, $\nu_{u}$ and $\nu_{r}$ are the inherent frequency of absorption, $f_{u}$ and $f_{r}$ the oscillator strength, and subscript $u$ and $r$ express the case of ultra-violet and infra-red, respectively. This formula means that electrons participate to absorption in ultra-violet region and atoms or ions do in infra-red. In other words, absorption in ultra-violet is due to the transition of electrons and in infra-red due to the vibration of the lattice. Therefore, it may be regarded that $\nu_{u}$ and $\nu_{r}$ correspond to two factors above mentioned respectively. To ascertain the contribution of $\nu_{u}$ and $\nu_{r}$ to the damage thresholds, we selected the absorption edge in ultra-violet and the peak position of absorption due to Si-O stretching in infra-red, which is commonly observed in many glasses, as the measure concerned with the inherent frequency.

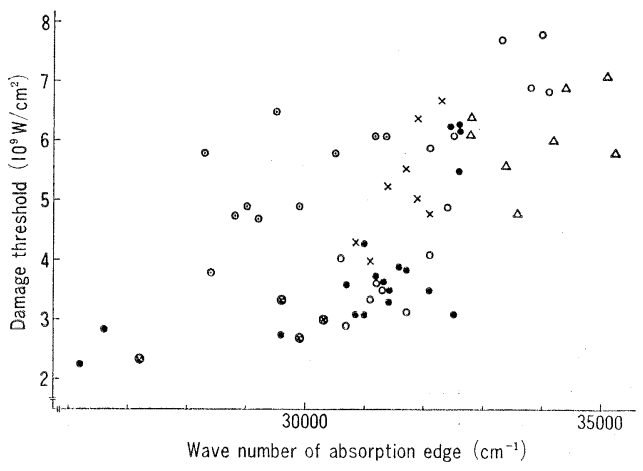

Fig. 5. Relation between the damage thresholds and the absorption edge in ultra-violet.

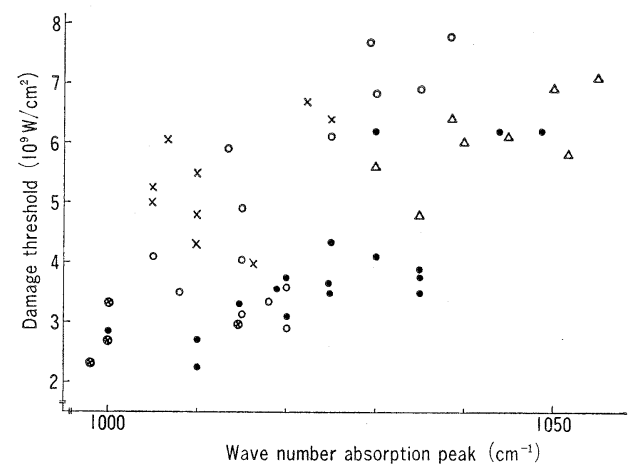

Fig. 6. Relation between the damage thresholds and the peak position of absorption in infra-red.

Relation between the thresholds and these values is given in Fig. 5 and 6 respectively. The thresholds are found to correlate with both the absorption edge and the peak position, and accordingly the significance of the inherent frequency of absorption against the thresholds was established. Then, considering that variable region of the peak position is much narrow, it could be pointed out that the correlation of the thresholds with the peak position is stronger than the case with the absorption edge. This is reasonable, as seen from (1), since the threshold is proportional to $\delta^{-3 / 2}$.

It is often the case that there are difference in the thresholds, even though glasses have same absorption edge and the peak position. This suggests that other factors besides the inherent frequency participate to the variations in the thresholds. For example, it is considered in the glasses containing $\mathrm{La}_{2} \mathrm{O}_{3}$ that the term of the compactness, $N$ in (2), has a relatively large contribution; about these types of glasses the same deviation as shown in Fig. 4 is noted in Fig. 5 .

About the glasses having a complexity in the 
that the thresholds are higher in the glasses with the low dispersion than those with the high dispersion. In other words, the thresholds increase as the dispersion decreases. Since Abbe's number could be regarded as the function of the inherent frequency of absorption ${ }^{10)}$, this result shows that the thresholds increase with the increase of the frequency.

Fig. 4 shows a plot of the thresholds against average dispersion defined as $n_{\mathrm{F}}-n_{\mathrm{C}}$, where $n_{\mathrm{F}}$ and $n_{\mathrm{C}}$ are the refractive indices measured with $\mathrm{F}$ and $\mathrm{C}$ line respectively. The thresholds of the glasses containing $\mathrm{La}_{2} \mathrm{O}_{3}$ are found to be high in comparision with the other glasses having about the same average dispersion. Since it is known that the average dispersion approximately depends on the compactness of glass structure as well as the inherent frequency ${ }^{10)}$, this result may be attributed to the increase of the compactness characteristic of the glasses containing $\mathrm{La}_{2} \mathrm{O}_{3}$; it is considered that the increase of the average dispersion is chiefly due to the increase of the compactness rather than due to the decrease of the inherent frequency, and the thresholds in the glasses with the dispersion thus given are relatively high.

After all, we may conclude that the durability of glass against laser light largely depends on the

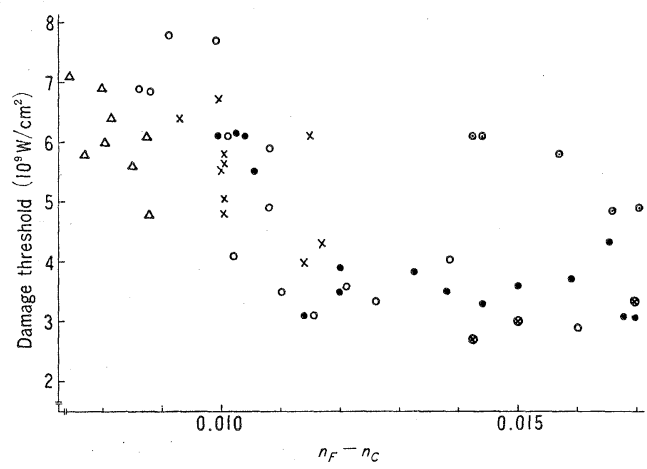

Fig. 4. Relation between the damage thresholds and the average dispersion, $n_{\mathrm{F}}-n_{\mathrm{C}}$.

Table 3. Relation between the damage thresholds and some physical properties.

\begin{tabular}{lccccc}
\hline $\begin{array}{c}\text { Glass } \\
\text { designation }\end{array}$ & $\begin{array}{c}\text { Damage } \\
\text { threshold } \\
\left(10^{9} \text { W/ } \mathrm{cm}^{2}\right)\end{array}$ & $\begin{array}{c}\text { Thermal } \\
\text { diffusivity } \\
\left(\mathrm{cm}^{2} / \mathrm{sec}\right)\end{array}$ & $\begin{array}{c}\text { Softening } \\
\text { point } \\
\left({ }^{\circ} \mathrm{C}\right)\end{array}$ & $\begin{array}{c}\text { Expansion } \\
\text { coefficient } \\
\left(\times 10^{7}\right)\end{array}$ & $\begin{array}{c}\text { Young's } \\
\text { modulus } \\
\left(\mathrm{kgW} / \mathrm{mm}^{2}\right)\end{array}$ \\
\hline BaK 1 & 7.70 & 4.33 & 749 & 88 & 7270 \\
BaLF 5 & 4.07 & 4.00 & 636 & 106 & 7310 \\
BaF 6 & 3.48 & 3.48 & 750 & 83 & 6760 \\
BaSF 4 & 3.36 & 3.20 & 657 & 97 & 8730 \\
SK 7 & 5.53 & 3.61 & 764 & 76 & 8190 \\
SSK 2 & 4.28 & 3.25 & 767 & 76 & 7780 \\
KF 8 & 6.16 & 4.13 & 613 & 100 & 5680 \\
LLF 1 & 3.50 & 4.18 & 592 & 97 & 6190 \\
LF 2 & 3.33 & 3.52 & 594 & 100 & 6080 \\
F 8 & 3.59 & 3.76 & 590 & 96 & 5900 \\
\hline
\end{tabular}

inherent frequency of absorption, but, on the other hand, the increase of compactness of oxygen ion in glass structure is also effective to increase the durability.

Furthermore, it was also found that the thresholds correlated with refractive indices. Namely the thresholds tend to increase as refractive indices become lower. However, the correlation is not so clear as with the dispersion.

Representative results about relation between the thresholds and other physical properties are given in Table 3. Obvious correlation with the thermal diffusivity, which was determined with laser flash method, is recognized; in the glasses with the high thresholds, the thermal diffusivity is also high.

\section{Discussion}

4.1 Dominant factor regulating the durability of glass against laser light

About the damage of transparent dielectrics such as glass by laser light, various possible mechanisms have been proposed up to date $\mathrm{e}^{6), 11) \sim 14)}$, but the process leading to the damage is not yet fully understood. For instance, the multiphoton process alone can not explain the existence of microplasma produced prior to the damage and order of the damage thresholds is not necessarily related to the number of free electrons liberated by the multiphoton ionization ${ }^{13)}$.

In all the theories of the damage, the liberation of free electrons and the electron-lattice interaction play important role ${ }^{6), 12) \sim 16)}$. Recently, Sharma and Rieckhoff considered that through the process in which free electrons liberated in the early part of a laser pulse by the multiphoton ionization absorb energy from the remainder of the pulse by inverse bremesstrahlung mechanism and multiply, the generation of the plasma which has essentially a role of the damage is caused, and evaluated the damage threshold from the point of view of the laser flux required for causing such multiplication ${ }^{16)}$. Namely, the photon flux, $S$, at which as to electrons the average rate of gain of energy is balanced by the average rate of loss is given by

$$
S=v m \bar{W} \delta^{-3 / 2} / h \omega M
$$

where $v$ is the velocity of electrons, $m$ the mass of electrons, $M$ the mass of atoms or ions in lattice, $h \omega$ the photon energy of laser light and $\bar{W}$ the average electron energy which is equal to half the ionization energy, respectively. If the photon flux of incident laser light is larger than the value given by (1), the rate of gain of energy exceeds the rate of loss due to elastic collisions with the 
(1965).

4) J. Martinelli, J. Appl. Phys. 37, 1939-40 (1966).

5) R.A. Miller and N.F. Borreilli, Appl. Opt. 6, 165-66 (1967).

6) E.S. Bliss, ASTM Spec. Technol. Pub. No. 469 (1969).

7) T. Komiyama and T. Ueno, Bull. Government Ind. Res. Inst., Osaka 24, 11-16 (1973).

8) T. Izumitani, "Kogaku Gijutsu Hand-Book" Asakura (1958) p. 568.

9) I. Suzuki and T. Izumitani, Yogyo-Kyokai-Shi 80 [10] 388-94 (1972).

10) T. Izumitani, Report Osaka Ind. Res. Inst., [311] 26-37 (1958).
11) R.Y. Chia et al., Phys. Rev. Letters 13, 479-82 (1964).

12) G.M. Zverev et al., Sov. Phys. JETP 26, 105357 (1968).

13) B.S. Sharma and K. Rieckhoff, Canad. J. Phys. 45, 3781-91 (1967).

14) H. Frohlich and F. Seitz, Phys. Rev. 79, 526-27 (1950).

15) F. Seitz, ibid. 76, 1376-93 (1949).

16) B.S. Sharma and K. Rieckhoff, Canad. J. Phys. 48, 1178-91 (1970).

17) M. Ueda et al., "Bussei Butsuri-Gaku Koza" vol. 9, Kyoritsu (1958) p. 30.

[Received August 16, 1973]

\section{レーザーによる光学ガラスの損傷}

\section{小見山 亭・上野 カ・馬渡正秀* \\ (大阪工業技術試験所, * (株) 小原光学硝子製造所)}

大出力ガラスレーザー用素子の開発に関する研究の一 部として,レーザー光に対する耐久性の高いガラスを得 るために, 種々の光学ガラスについて, Qスイッチガラ スレーザー光による内部損傷の闇值を測定し, 耐久性と ガラス組成の関係，およびそれを支配する要因などに関 して検討した。

その結果, 損傷の閾値は, ガラス形成酸化物の含有量 が増すにつれて増加すること, 修飾酸化物として $\mathrm{BaO}$ や $\mathrm{La}_{2} \mathrm{O}_{3}$ を含むガラスでは比較的大きいが, $\mathrm{PbO}$ 含有 ガラスでは著しく小さいことなどがわかった.さらに, 閾值は, ガラスの分散が減少するにつれて, また, 熱拡 散率が増すにつれて，それぞれ増大することを見出し
た.

損傷の閾值と分散との相関に基づいて，レーザー光に 対するガラスの耐久性は，主として，ガラスの固有吸収 の振動数に依存し，それが大きいほど高いといえるが， ガラス構造における酸素イオンの充填度が大きいこと も，耐久性の増大にとって効果があると考えられた。こ のことは, 損傷の閾值は, 網目構造の振動数および酸素 イオン内での電子遷移エネルギーなどの大きさに依存す ると考えられる, Sharma らが提案している損傷の機構 との関連において説明することができる.

(8/16/1973 受付) 